\title{
Geology of Ali Khanzai Block of Zhob Ophiolite, Balochistan, Pakistan
}

\section{Saeed Ur Rehmana, M. Ishaq Kakara, Muhammad Ayoub Khana ${ }^{*}$, Abdul Naeem ${ }^{b}$}

a Centre of Excellence in Mineralogy, University of Balochistan, Quetta, Pakistan

${ }^{\mathrm{b}}$ Geological Survey of Pakistan, Quetta, Pakistan

*Corresponding Author E-mail: ayoub.cemuob@gmail.com

\section{DOI: 10.2478/pjg-2021-0004}

\section{Abstract:}

The Zhob Ophiolite is divided into Naweoba, Omzha and Ali Khanzai blocks. Ali Khanzai Block is further divided into ultramafic, mafic, and lava units which are surrounded by sedimentary rocks successions. The ultramafic unit contains ultramafic tectonic and ultramafic cumulate, mafic rock unit consists of foliated and layered gabbros and mafic dykes are doleritic in composition. Volcanic-volcaniclastic-pelagic rocks unit consists of thick volcanic pillow basalt, hyaloclastite, bedded chert, pelagic limestone and hemipelagic mudstone. The metamorphic sole rocks are tectonically high distorted and dismembered, comprising of amphibolite and greenschist facies. They might have formed through the process of early intra-oceanic obduction of the ophiolite. All units make thrusted contacts and are highly deformed. Petrography and geochemical studies divide the Ali Khanzai Block into rock types such as gabbro, olivine gabbro, dolerite, basalt, basaltic andesite and basaltic trachy-andesite, chert, mudstone, and limestone, dunite, serpentinite, harzburgite, and wehrlite. Mafic dyke intrusions crosscut mantle rocks of block. The mantle rocks are altered, deformed, and deeply weathered, maybe residual melting of enriched mantle peridotite. The contact relationship of dolerite dykes with peridotite indicta that they are late magmatic intrusions. The Crustal gabbros are partially chloritic and sericitic and occur within mantle peridotite, , they may have formed from fractional crystallization in a magma chamber. The volcanicvolcaniclastic-pelagic sediments surround mantle and crustal rock units. It might be a mélange in nature is much like that of the Bagh Complex found beneath the Muslim Bagh Ophiolite, and other ophiolites around the world.

Keywords: Ophiolite, mélange, peridotite, gabbro, lava.

\subsection{Introduction}

An ophiolite is a fragment of uplifted oceanic crust and island arc with the underlying uppermost mantle that has been emplaced tectonically along continental margins, fused in island arc and found as an altered and deformed block during orogenic processes [1]. Naturally, the ophiolites are found either as dismembered or intact having nearly complete stratigraphy [2]. When an ophiolite is highly deformed and dismembered which is characterized by a lack of continuous lithological sequence and enclosure of remnants of rocks of all size and unable to reconstruct its complete stratigraphic sequence that ophiolitic body is termed as mélange [3]. Therefore, the suture zones occupied by ophiolites and undelaying mélanges have a huge importance in the history of geology to restructure its tectonic evolution from its beginning to last emplacement [4].

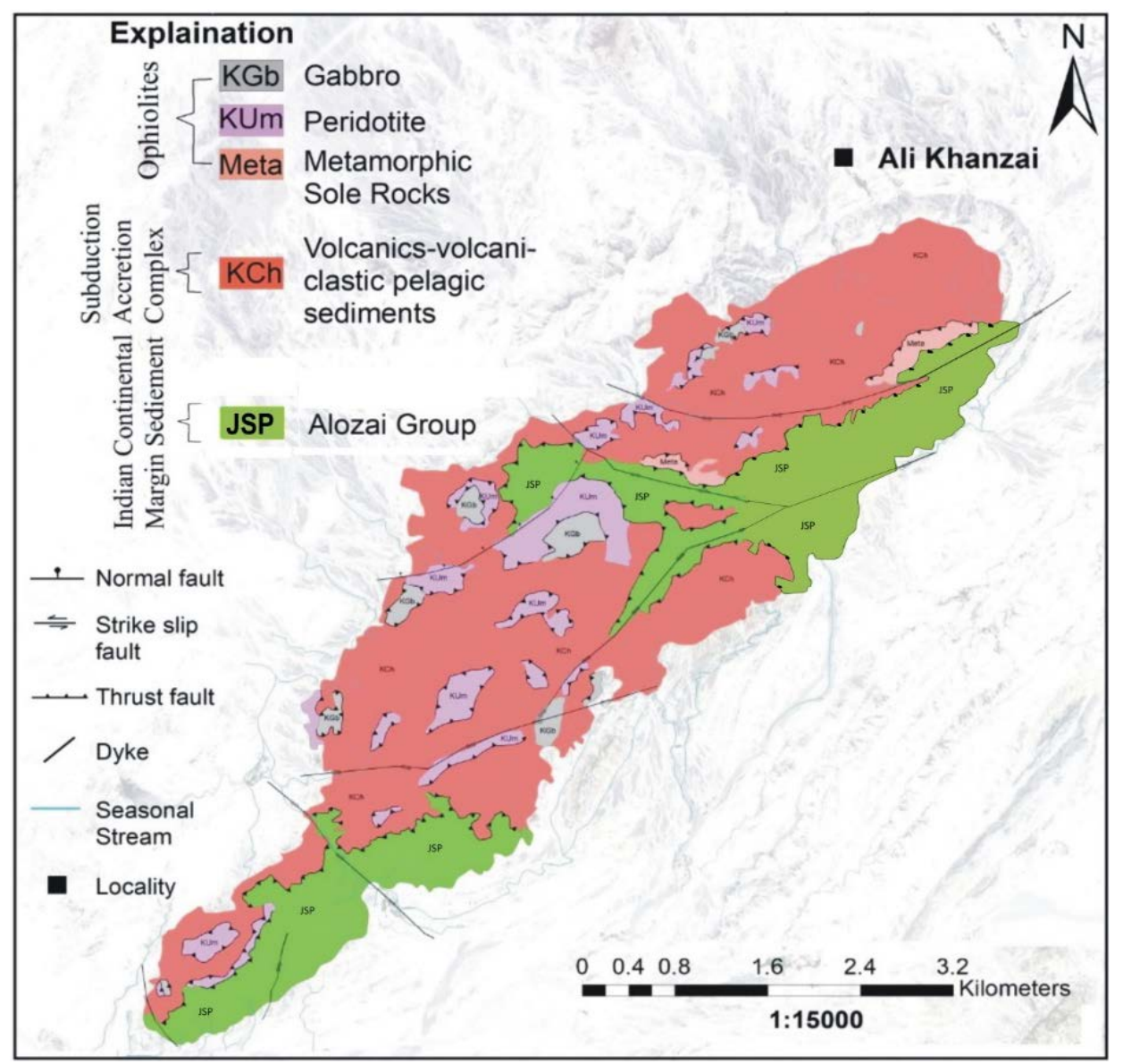

Figure 1. Geological Map of Ali Khanozai block of Zhob ophiolite, Northern Balochistan, Pakistan. 
In Pakistan, the ophiolites that occupy the axial belt are exposed both along the northern and western suture of the Indian plate and with the afghan block of the Eurasian plate. [5]. In Balochistan along the suture, the largest bodies of these ophiolites are best exposed namely, Zhob Valley Ophiolites and Bela Ophiolite [6]. The Zhob Valley Ophiolites comprise Zhob, Khanozai and Muslim Bagh Ophiolites [7]. Though the Zhob Ophiolite is a well-exposed and is not well-studied ophiolite. The ophiolite is divided into three dismembered blocks namely, Naweoba, Ali Khanzai and Omzha blocks. The Ali Khanzai block (the topic of this study) is one of the largest bodies of Zhob ophiolite, is exposed about $20 \mathrm{~km}$ in SW of Zhob town (Figure1). However, the ophiolite has a nearly complete ophiolitic sequence but is not assembled in a proper stratigraphic sequence. The block comprises a residual mantle that is quite deformed and mixed up, underlain by a crustal section of ultramafic to mafic cumulate and underlying mélange. The mantle section is overlain by the lava units with pelagic sediments. This paper presents the geology, petrography, and major elements geochemistry of the rocks of Ali Khanzai block to determine their nature and composition.

\subsection{Regional and Local Geology}

The rock formations of the Calcareous zone are exposed in the Zhob area. The zone rock units are found stratigraphically beneath the Ali Khanzai Block, which comprises repeated thrust sheets of upper Triassic to the Middle Jurassic sedimentary rocks of the Alozai Group [8]. The Alozai Group is composed of medium to thick-bedded limestone, shale, and a lesser amount of marls, sandstone, and occasional conglomerate. The limestone dominated part of the group may be Loralai Formation while the shale and other lithologies represent the Spingwar Formation. The limestone and shale of the formations are quite deformed and recrystallized. The Calcareous zone is thrusted by the Suture zone which occupies the Zhob ophiolite $[9,10]$. The Zhob ophiolite has been sub-divided into three separate blocks; the Omzha block, the Naweoba block and the Ali Khanzai block. Among these blocks, the Ali Khanzai is the second-largest block after the Naweoba block [11] The Ali Khanzai block is lying unconformably underneath the sediments of the Flysch zone. The Flysch zone is situated northwest of the suture zone $[12,13]$. The Eocene Nisai Formation (oldest and lowest Formation) is comprised of marine limestone, sandstone, shale, marl and conglomerate, is unconformably overlying the Zhob ophiolite [14]. The Nisai Formation is increasingly succeeded by the Khojak Formation of Oligocene age and Multanai Formation of Pliocene-Pleistocene age [11, 15].

\subsection{Materials and Methods}

Detail fieldwork has been carried out in the Ali Khanzai block of the Zhob Ophiolite. For mapping of the area, the Google Earth features were used (Figure 1). Rock samples from different locations of the study area were collected. During fieldwork, we used a random sampling technique for the collection of rock samples. Almost 50 samples were collected for petrographic and geochemical studies from different parts of the Ali Khanzai block. About thirty-five thin sections were prepared for petrographical studies and are examined under Olympus BX51 Fluorescence Microscope at the laboratory of National Centre of Excellence in Geology, University of Peshawar, Pakistan. A total of 20 samples of different rock including 8 from gabbro, 8 from mafic dyke, and 4 from Basalt were selected for geochemistry and were analyzed for concentration of major oxides and trace elements using X-ray Fluorescence (XRF) and Atomic Absorption Spectrometry (AAS), respectively. Before analysis, the weathered surface was removed and the fresh part was powdered using a mill and made powdered up to the size of $<0.074 \mathrm{~mm}$. To determine the loss on ignition (LOI), about $12 \mathrm{gm}$ of powder of each sample was dried and heated up for three hours in the oven up to the temperature of $900-950^{\circ} \mathrm{C}$. The XRF analysis for major oxides was effectuated on fused disks called glass beads to remove the absorbed moisture. After cooling in the desiccators, $0.7 \mathrm{gm}$ of each sample was mixed with $7 \mathrm{gm}$ of flux (mixture, of lithium metaborate and lithium tetraborate). We added about two to three drops of releasing agent (lithium iodide) to the mixture, and then the subsequent was pressed to form a disc. The fused disc was examined for major element concentration using a WD-XRF. Trace elements such as $\mathrm{Cr}, \mathrm{Ni}, \mathrm{Co}, \mathrm{Zn}, \mathrm{Ag}, \mathrm{Cu}$, and $\mathrm{Pb}$ were carried by using Atomic Abortion Spectrometry (AAS). These powdered samples were dissolved in Teflon beakers using hydrofluoric acid and aqua-regia $\left(3 \mathrm{HCl}: 1 \mathrm{HNO}_{3}\right)$ to get liquid solutions [16]. After the preparation of samples 'solution, it was run on Atomic Absorption Spectrometry using the cathode lamp of the given sample and the data was noted in values of parts per million (ppm) (Table 1) 
Table 1. Major oxide (wt \%) and selected trace element (ppm) concentration of the analyzed samples from the Ali Khanzai block of Zhob Ophiolite.

\begin{tabular}{|c|c|c|c|c|c|c|c|c|c|c|c|c|c|c|c|c|c|c|c|c|}
\hline Sample No & AK-2 & AK-33 & AK-36 & AK-37 & AK-38 & AK-40 & AK-43 & AK-51 & AK-23 & AK-18 & AK-29 & AK-31 & AK-38 & AK-46 & AK-47 & AK-50 & AK-08 & AK-13 & AK-20 & AK-44 \\
\hline Rock types & G & G & G & G & G & G & G & G & D & D & D & D & D & D & D & D & B & B & B & B \\
\hline $\mathrm{SiO2}$ & 47.89 & 40.85 & 39.68 & 46.13 & 48.17 & 42.69 & 55.36 & 42.71 & 52.76 & 54.53 & 55.58 & 53.53 & 55.31 & 69.03 & 70.48 & 45.46 & 53.1 & 52.58 & 48.21 & 41.33 \\
\hline Ti03 & 0.03 & 0.01 & 0.02 & 0.01 & 0.03 & 0.01 & 0.11 & 0.02 & 0.34 & 0.23 & 0.47 & 0.21 & 0.36 & 0.07 & 0.08 & 0.04 & 0.51 & 0.57 & 0.34 & 0.51 \\
\hline Fe203t & 0.99 & 0.54 & 2.53 & - & 0.03 & 0.15 & 0.11 & - & 1.06 & 0.56 & 0.54 & 0.56 & 0.64 & - & 0.12 & 1.2 & 0.42 & 0.64 & 1.06 & 0.61 \\
\hline MnO2 & 0.02 & 0.01 & 0.04 & 0.01 & 0.01 & 0.02 & 0.02 & 0.01 & 0.06 & 0.14 & 0.03 & 0.14 & 0.06 & 0.02 & 0.02 & 0.02 & 0.06 & 0.04 & 0.06 & 0.04 \\
\hline Mg02 & 11.28 & 14.05 & 20.15 & 11.94 & 12.47 & 21.87 & 9.98 & 7.75 & 15.25 & 6.06 & 5.13 & 7.06 & 3.29 & 1.76 & 1.35 & 17.44 & 3.6 & 5.13 & 14.25 & 5.13 \\
\hline CaO & 3.1 & 15 & 12 & 3.2 & 8.1 & 7.1 & 6.3 & 3.8 & 9.7 & 5.6 & 4.6 & 3.5 & 1.7 & 1.2 & 0.7 & 5.8 & 11 & 4.6 & 11 & 4.6 \\
\hline K20 & 0.9 & - & 0.1 & 0.5 & - & 0.4 & 0 & 0.1 & - & 0.1 & 0.9 & 0.1 & 0.3 & 0.2 & 0.3 & 1.1 & 1.7 & 0.9 & 0.1 & 0.9 \\
\hline $\mathrm{Na} 2 \mathrm{O}$ & 4.8 & - & - & 3.7 & - & - & 0.5 & 9.9 & 7.5 & 4.9 & 7.1 & 4.9 & 12 & 11 & 8.9 & 1.5 & 4.1 & 8.1 & 4 & 2.9 \\
\hline P205 & - & - & - & - & - & - & 0.1 & - & 0.1 & 1.8 & 0.4 & 1.8 & 0.3 & 0.1 & 0.1 & - & 0.4 & 0.5 & 0.1 & 0.5 \\
\hline LOI & 6.8 & 6.9 & 8.4 & 5.2 & 4.3 & 7.2 & 3.2 & 5.8 & 3 & 1.8 & 3.2 & 3.5 & 2.9 & 2.1 & 1.9 & 5.5 & 14 & 6.7 & 2.9 & 6.9 \\
\hline Total & 98.75 & 102.52 & 102.9 & 99.26 & 100.5 & 102.2 & 99.19 & 100.2 & 101.7 & 97.73 & 101.9 & 99.27 & 102.8 & 102.3 & 101.9 & 100.6 & 104.1 & 105.7 & 93.53 & 83.34 \\
\hline Ag & 2.25 & 0.05 & 0.2 & - & 0.05 & 0.05 & - & 1.65 & 0.2 & - & - & - & - & - & - & 1.2 & - & 1.35 & 0.2 & - \\
\hline Co & 42.55 & 30.75 & 20.75 & 27.7 & 20.35 & 22.5 & 22.5 & 23 & 21.65 & 10.95 & 36.35 & 36.35 & 22.5 & 16.25 & 29 & 39.3 & 24.55 & 43.9 & 5.1 & 30.9 \\
\hline Cu & 56.35 & 339.95 & 37.6 & 46.65 & 33.4 & 45.9 & 299.9 & 36.2 & 806.5 & 634 & 202.3 & 173.6 & 157.9 & 511 & 143 & 125.8 & 120.9 & 111.5 & 428.8 & 402.8 \\
\hline $\mathbf{P b}$ & 52.85 & 67.95 & 32.15 & 51.1 & 23.4 & 46.9 & 22.25 & 51 & 68.1 & 59.25 & 56.2 & 25.85 & 75.7 & 36.35 & 24.7 & 26.45 & 62.3 & 46.4 & NIL & 65.95 \\
\hline $\mathbf{Z n}$ & 19 & 18.95 & 13.7 & 9.6 & 9.45 & 16.3 & 16.3 & 12.3 & 15.1 & 10.65 & 76 & 41.85 & 109.3 & 31.9 & 30.9 & 19.65 & 51.15 & 45.1 & 9.95 & 38 \\
\hline $\mathbf{N i}$ & 218.7 & 139.6 & 105.3 & 53.25 & 105.3 & 45.5 & 7.05 & 49.75 & 9.4 & 1.95 & 20.6 & 27.3 & 1.3 & 1.45 & 16.4 & 124.2 & 11.85 & 14.7 & 2.5 & 30.65 \\
\hline
\end{tabular}

Note: AK = Ali Khanzai block, LOI = loss on ignition, G=gabbro, B=basalt, D= dolerite, Fe203t=total iron. 


\subsection{Geology and Petrography of Ali Khanzai Block}

\subsection{Field Features}

The Ali Khanzai block consists of a mix of the ophiolitic rock sequence and is underline by metamorphic sole rock. The ophiolitic rock sequence ranging from mantle rocks to crustal rock. Numerous mafic dykes cross-cut the mantle rocks of the ophiolite.

\subsubsection{Ultramafic Rock Unit}

Generally, the ultramafic rock section of an ophiolite is subdivided into two units. (i) Ultramafic tectonite and (ii) ultramafic cumulate, however in the Ali Khanzai block of Zhob Ophiolite, these rock units are highly deformed and tectonically disturbed. It is not possible to divide them into tectonite and cumulates units, Although the Ali Khanzai block has an ultramafic rock unit, mainly composed of serpentinized harzburgite, dunite with a minor wehrlite. Generally these rock bodies are small and irregular which can easily be distinguished from other igneous rocks; gabbro, volcanic and the sedimentary rock units (Figure 1). The mantle section is having structural contact with various rock, but typically its contact with crustal gabbroic rocks are more common (Figure 2a). Generally, most of the ultramafic rocks of the Ali Khanzai block are moderate to entirely altered into serpentinites. The harzburgite found is medium to coarse-grained and appears brownish to black on both weathered and fresh surfaces. In the field area, the harzburgite is partially to completely altered into serpentinite and occurs as massive bodies and are widespread in the ultramafic rock unit. The dunite on weathered surfaces is brown to reddish-brown in color, while its fresh surface is green to olive green. In the Toi zawar area, a small concentration of chromite in the form of lenses and veins is found in dunite. Wehrlite is mostly altered, as its small bodies are unable to be mapped.

\subsubsection{Mafic rock Unit}

The southwestern portion of the Ali Khanzai block is characterized by small and isolated bodies of gabbroic rock (Figure1). The crustal section comprises gabbro and olivine-gabbro forming a small outcrop embedded in serpentinized peridotites. These rocks are whitish gray to dark gray in color and medium to coarse-grained in texture. It is highly deformed, less well-developed occurs within peridotite, that is elongated looks like a dyke. In the Ali Khanzai block, we have not found a sheeted dike complex. Generally, the gabbroic rocks trend NW-SE and dip about 25 to 30 -degree SW or NW. The contacts of gabbroic bodies are sheared and faulted and covered at some places. In some areas, gabbroic rocks have thrusted contacts with peridotite and volcanicvolcaniclastic rocks (Figure 2b). Structurally they are classified into foliated and layered gabbro. These layering in layered gabbro are characterized by the plagioclase and pyroxene of white and black colors, respectively and about a few millimeters to a centimeter in thickness.

\subsubsection{Mafic dykes}

Numerous mafic dykes were found in the Ali Khanzai block of Zhob Ophiolite which cross-cut the mantle rocks of the ophiolite. These mafic dykes range from one to three meters in thickness and extend up to hundreds of meters (Figure 2c). These mafic dykes are almost parallel and strike almost $130^{\circ}$ to $150^{\circ}$ (Figure 1). The dykes are typically doleritic in composition.

\subsubsection{Volcanic-volcaniclastic-pelagic rocks}

Ali Khanzai block also comprises volcanic-volcanoclastic-pelagic rocks. The rocks unit contains thick volcanic pillow basalt, associated with hyaloclastite, bedded chert, pelagic limestone and hemipelagic mudstone, the volcanic rocks are predominantly basalts with amygdaloidal and vesicular structure. The volcanic-volcanoclastic-pelagic rocks are associated with chert, are quite deformed, weathered and forming high landforms. Basalt is the dominant rock of this unit made a considerable part of the unit (Figure 1). It surrounds the mantle peridotite and gabbroic rocks and makes a thrusted contact with them. The volcanic rocks in the outcrop that are associated with hyaloclastite are dark brownish in color. The hyaloclastite is comprised of grains of dark volcanic, ultramafic and some limestone fragments. Although these volcanic rocks occur in different forms the important structures are pillows, sheets flows, tubes, and beds. The pillows and tube structures in basalt are irregular and poorly developed but are closely packed and are about 0.5-1 $\mathrm{m}$ in diameter (Figure 2d). Amygdaloidal and vesicular structures in basalt are identified in the field. The amygdule is almost filed with secondary minerals like calcite, quartz. The vesicular structures occur occasionally and are tiny filled with mostly calcite and some quartz.. While in some localities, basalt has intercalation of limestone and chert. The pelagic sediment typically overlies the volcanic rocks and other rock units and is composed of limestone, chert, and cherty shale. Basalt is the predominated volcanic rock of the study area, has, thrusted and conformable contacts with gabbro and peridotite. While at many localities, basalt has associated chert and thrusted over Loralai Limestone (Figure 2e). the chert found in the field area is thin to thick-bedded, making high cliffs, they have different colors i.e., maroon, red, green cream, and gray. But maroon color is abundant. Mudstone forms thin layers and interbedded with chert. 

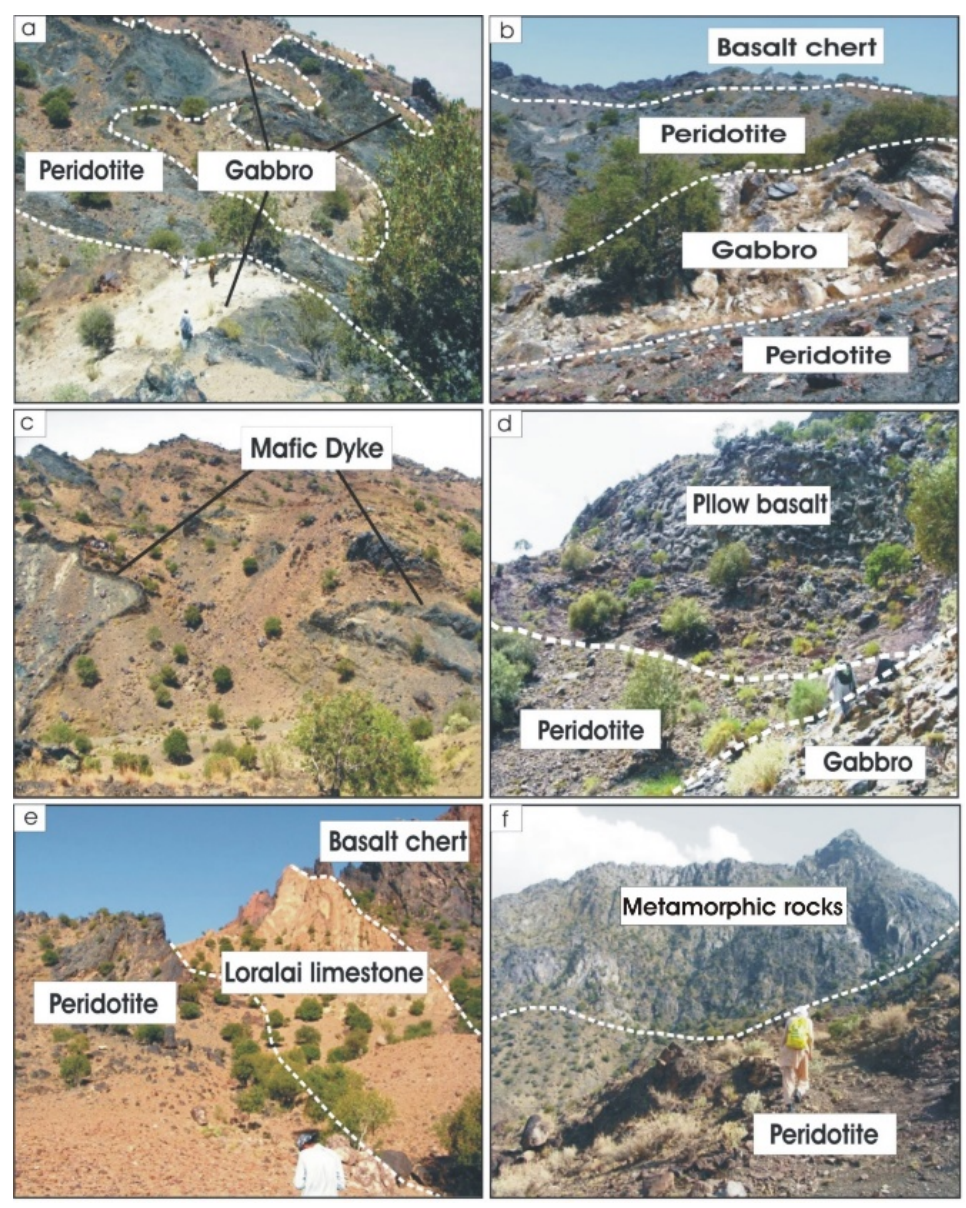

Figure 2. Field Photographs showing; (a) structural contact of mantle peridotite with crustal gabbro; (b) Gabbroic rock having thrusted contact with peridotite at the base and Volcanic-volcaniclastic-pelagic rocks at the top; (c) Mafic dykes crosscutting through the mantle peridotite of the block; (d) Pillows and tube structures in the basalt of Volcanic-volcaniclastic-pelagic rocks; (e) An outcrop of Loralai member of Alozai Group overlain by Volcanicvolcaniclastic-pelagic rocks unite and underlined by mantle peridotite; (f) Metamorphic sole rocks of Ali Khanzai block, forming high peaks in Toi Zawara area.

\subsubsection{The metamorphic sole rock.}

The Ali Khanzai block comprised of thick exposure and the vertical bed of metamorphic sole rocks. The sole rocks consist of amphibolite and chlorite/ greenschist facies rocks. The sole rocks form high peaks in the Toi Zwar area (Figure 2f). They are trending N-S and dip with a high degree toward NW or W.

\subsubsection{Alozai Group}

The Ali Khanzai block is surrounded by sedimentary successions of the Alozai Group ( Triassic-Jurassic), and it is exposed as a tectonic klippe. Stratigraphically the Alozai Group has been divided into two members namely (a) Loralai Formation (Lower to Middle Jurassic) (b) Spingwar Formation (Upper Triassic to Lower Jurassic).

\section{a) Loralai Formation.}

The name of the Loralai Formation was first given later in the town of Loralai [11]. In the study area, it shows parallel bedding of limestone with minor shale and marl. The Formation is best exposed on the southeast of the Ali Khanzai block. The limestone is light to dark grey in color with 1 to 1.5 feet in thickness and almost dipping 40-45 degrees towards the E. The shale of the formation is calcareous; it is dark grey to black in color. The marl is thin, soft with a minor amount and found as greenish-grey in color.

\section{b) Spingwar Formation}

The Spingwar Formation is widely exposed to the southeastern part of the Ali Khanzai block. The Formation was firstly named by [17] and presently it is included in the Alozai Group by $[17,18]$. The Formation comprises thin-bedded dark grey limestone with interbedded shale and marl. In the Toi Zawara area, the Formation is non-conformably overlain by Volcanic-volcaniclastic-pelagic rocks section, and also thrusted back on ultramafic rocks unit. Fossils of ammonites were found in the Formation.

\subsection{Petrography}

\subsubsection{Harzburgite}

Mineralogically, harzburgite comprises anhedral grains of olivine $(\sim 15 \%$ mostly altered to antigorite), with euhedral to subhedral grains of pyroxene $(\sim 15 \%)$. Pyroxene is mostly orthopyroxene with medium to coarse-grained and subhedral to anhedral in shape. These crystals of olivine and orthopyroxene grains are surrounded mostly by serpentinized groundmass ( $65 \%$; mostly antigorite and lizardite) and form interlocking texture. Some orthopyroxene grains give an inverted pigeonite texture that is encircled in the serpentinized matrix. A small amount of magnetite occurs as microcrystalline material along the joints and in the fractures making an irregular network in the rock. The spinels are usually anhedral in shape. 

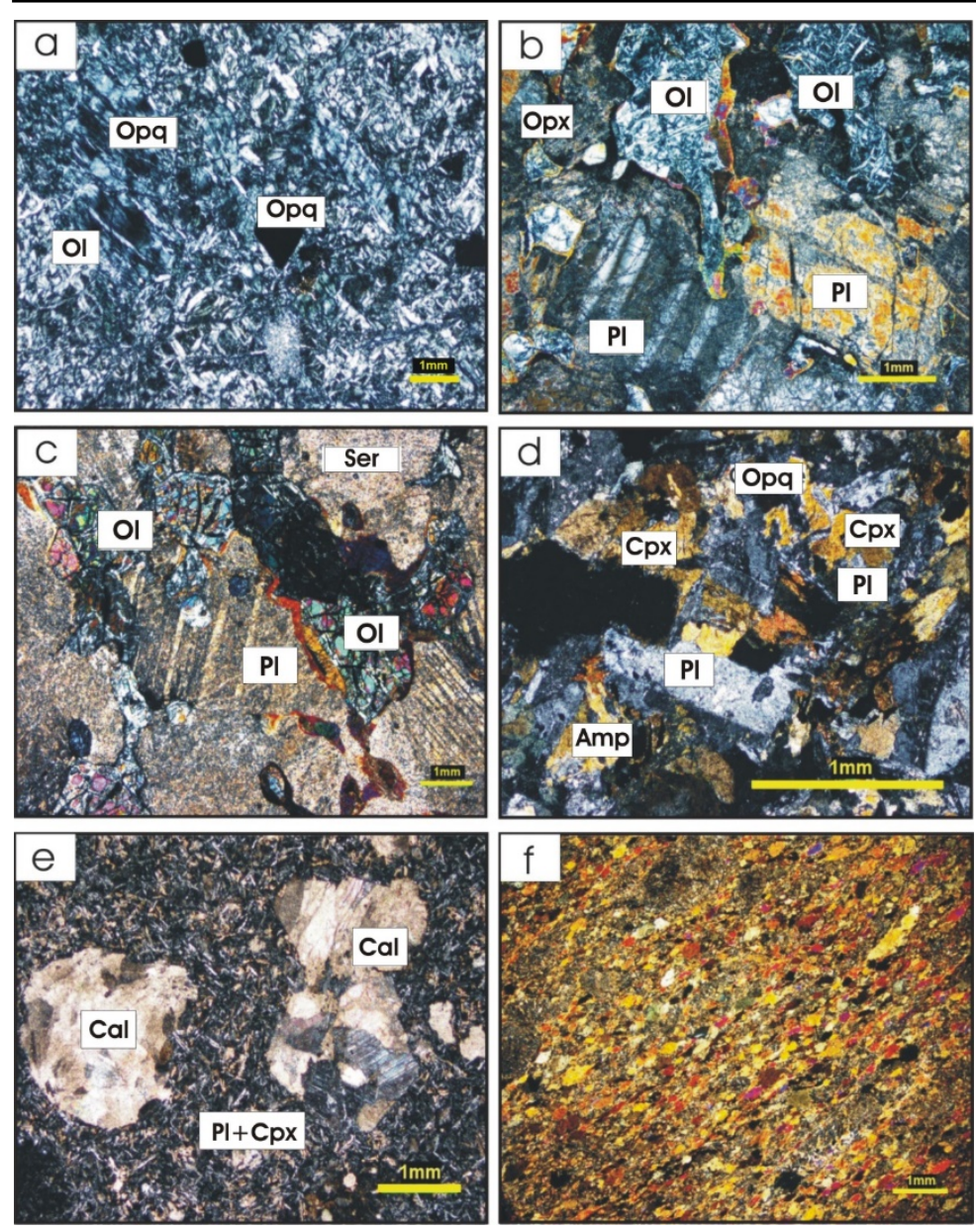

Figure 3. Microphotographs: (a) Mesh texture in dunite formed after the serpentinization olivine (XPL); (b) Gabbro showing polysynthetic plagioclase lath and occasional zoning with some olivine crystals forming ophitic texture (XPL); (c) Olivine Gabbro shows serpentinized olivine with moderately to welldeveloped Coronitic texture surrounded by altered plagioclase (XPL); (d) Dolerite showing ophitic to subophitic texture with plagioclase lath surrounded by clinopyroxene (XPL); (e) Vesicular Basalt shows vesicles filled by calcite in the groundmass of feldspar (XPL); (f) Greenschist facies with the subparallel alignment of plagioclase and chlorite with accessory minerals showing well-developed schistosity. The abbreviations of minerals are taken from [43].

\subsubsection{Dunite}

Dunite contains abundantly olivine and serpentine with minor clinopyroxene and accessory spinel, and iron oxides. The olivine (altered mostly to serpentine) occurs as a subhedral to anhedral form with no relief in the plane and cross-polarized light. While in some thin sections, olivine is present as the relict cores and enclosed in fibrous serpentine forming mesh texture (Figure 3a). The clasts of pyroxene range from subhedral to anhedral. Chromite spinels are found both as accessory minerals, as well as large, segregated crystals in dunite. The uneven fractures of olivine were occupied mostly by opaque minerals. The serpentine is grey to brownish grey in color. Most of the serpentine is lizardite and antigorite. The minerals percentage that constitutes the rock are $7-10 \%$ olivine, serpentine, $75-80 \%$, iron oxide, $2-4 \%$ and spinel up to $5 \%$.

\subsubsection{Gabbro}

Gabbro is holocrystalline, melanocratic, medium to coarse-grained and exhibits interlocking texture between plagioclase and pyroxene. Essential minerals that constitute the rock are $52-65 \%$ plagioclase, pyroxene (21-28\% clinopyroxene, $6-8 \%$ orthopyroxene) and $3-4 \%$ olivine, while $5-9 \%$ magnetite, serpentine, and chlorite are present in a minor amount as an accessory product. The plagioclase laths are generally subhedral in shape and coarse-grained ( $2.5 \mathrm{~mm}$ to $3 \mathrm{~mm}$ in size). It shows albite twinning while some plagioclase crystals show polysynthetic twinning and show occasional zoning (Figure $3 \mathrm{~b}$ ). In gabbro, pyroxene is mostly as clinopyroxene and in which augite is the main mineral with medium to coarse-grained in size and subhedral to anhedral in shape. The relief of clinopyroxene is medium to high. A tiny crystal of pyroxene and olivine may found enclosed in plagioclase. Olivine is medium-grained, subhedral to anhedral in shape found interstitially among the pyroxene and plagioclase crystals and has been altered to secondary product serpentine and may be chlorite. Olivine crystals appear to be mechanically deformed and display no proper cleavage.

\subsubsection{Olivine Gabbro}

Olivine gabbro mineralogically composed of $48-50 \%$ plagioclase, $26-27 \%$ pyroxene, $9-10 \%$ olivine and 6-7\% opaque minerals. Plagioclase is partially to completely altered to sericite. Chlorite and serpentine are found as secondary minerals. Plagioclase in olivine gabbro is more calcic (An 70-73) than in other gabbroic rock, with subhedral to anhedral in form, course-grained (2.2 $\mathrm{mm}$ up to $4 \mathrm{~mm}$ in size) and having albite twinning. Pyroxene is altered to chlorite which surrounds the plagioclase laths and is also found in the form of clusters. Serpentinized olivine is medium to coarse-grained in size, showing moderately to well- develop coronitic texture settled along the boundaries of altered plagioclase (Figure 3c). Irregular fractures are common in most of the olivine grains and display high relief. Zoned rims along the boundaries of olivine and plagioclase grains are developed. Iron oxides are present as secondary minerals that occur along the borders of the olivine grains. 
4.2.5. Dolerite

Dolerite is medium to fine-grained and often exhibits ophitic to the sub-ophitic texture (figure $3 \mathrm{~d}$ ). The average mineral composition of the doleritic rock is almost $15-35 \%$ of pyroxene and $55-65 \%$ plagioclase crystals with minor opaque minerals while chlorite and calcite are found as secondary phases.

\subsubsection{Basalt}

Mineralogically basalt comprises plagioclase, pyroxene (augite) and amphibole (hornblende) as phenocrysts, while chlorite, muscovite, epidote and opaque minerals are found as microcrystalline groundmass. Plagioclase and pyroxene both occur as phenocryst and groundmass. Plagioclase phenocrysts occur as laths and form an ophitic texture in a fine-grained groundmass. Some crystals are slightly fractured, polysynthetic, or multiple twining of plagioclase is also common and having an extinction angle between 38-43 degrees. While some grains are partly to entirely altered into sericite. Furthermore, clinopyroxene is characterized by augite which is also partly altered into chlorite. Vesicles are rounded in shape filled by secondary minerals such as calcite and quartz (Figure 3e). In some samples, groundmass and phenocryst are entirely crystalized forming a holocrystalline texture. Some picritic basalt having abundant olivine about $40-45 \%$ and having an average grain size of about $0.3-1.5 \mathrm{~mm}$. Plagioclase and pyroxene as phenocryst with subhedral to anhedral shapes and are scattered in groundmass with some opaque minerals showing porphyritic texture.

\subsubsection{Greenschist}

Petrographically, the greenschist are mainly comprised of chlorite and plagioclase with a variable amount of quartz, and epidote. The laths of plagioclase are highly deformed while the chlorite is the main mineral and is weakly pleochroic with pale green. The rock is fine-grained, having subparallel alignment of plagioclase with accessory minerals such as biotite, muscovite, opaque and quartz that help to form schistosity (Figure 3f).

\subsection{Geochemistry}

The Ali Khanzai block plutonic and volcanic rocks are classified by plotting on the total alkali versus $\mathrm{SiO}_{2}$ diagram (Figure 4 a-b; [19, 20]). The analyses of plutonic rocks inconsistently plot within the fields of gabbro, dolerite and rodingite (Figure 4a), while the analyses of volcanic rocks are plotted in the field of basalt, basaltic andesite and basalt-trachy-andesite (Figure $4 \mathrm{~b}$ ). The Ali Khanzai gabbros are classified by plotting on the total alkali versus $\mathrm{SiO}_{2}$ diagram (Figure 4a). Nearly all the samples fall almost within the gabbro field approving their gabbroic characteristics. Most of the gabbroic rock samples have very low values of total alkali and $\mathrm{SiO}_{2}$.
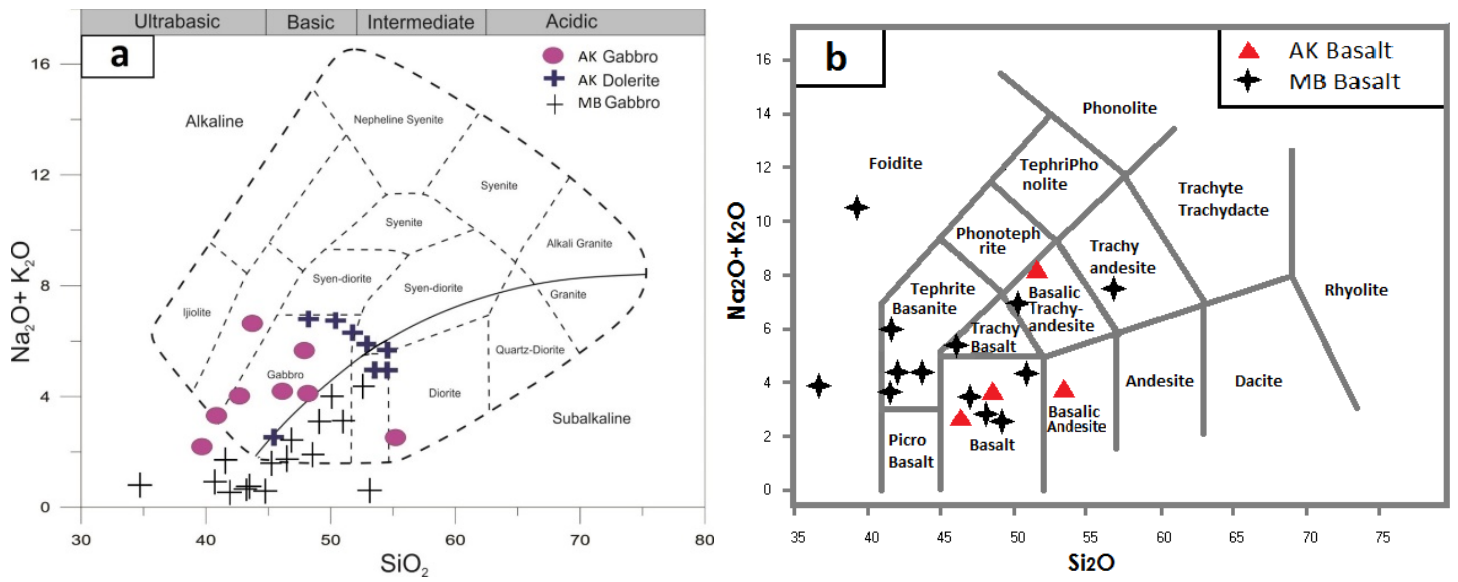

Figure 4. a- Total alkali versus SiO2 plots: (a) plutonic rocks [19] b- volcanic rocks [20], of the analyses from the rocks of Ali Khanzai block, Zhob Ophiolite. The MB data are published earlier in [23, 24] Key : AK = Ali Khanzai block, MB = Muslim Bagh Ophiolite.

\subsection{Geochemical Characteristics}

\subsubsection{Gabbroic Rocks}

The gabbroic rock of Ali Khanzai block have variable concentration (wt. \%) of $\mathrm{Al}_{2} \mathrm{O}_{3}(20-30), \mathrm{SiO}_{2}(40-55), \mathrm{TiO}_{2}(0.01-0.11), \mathrm{Na} 2 \mathrm{O}+\mathrm{K}_{2} \mathrm{O}(0.3-11), \mathrm{MgO}$ (822), $\mathrm{MnO}(0.01-0.04)$ and $\mathrm{CaO}$ (3-15), while the analyzed trace elements having concentration of (ppm) $\mathrm{Cr}$ (8-144), $\mathrm{Ni}$ (7-218), Cu (33-340), Co (20-43), Zn (9-19), $\mathrm{Ag}(0.05-2)$ and $\mathrm{Pb}(22-68)$.

\subsubsection{Dolerite}

The Doleritic rocks of the Ali Khanzai block have the concentration (wt. \%) of $\mathrm{Fe}_{2} \mathrm{O}_{3}(0.06-0.6), \mathrm{TiO}_{2}(0.04-0.5), \mathrm{Na}_{2} \mathrm{O}\left(1.5-12\right.$.), $\mathrm{K}_{2} \mathrm{O}(0.1-1.1)$, $\mathrm{MnO}(0.02-$ 0.14), $\mathrm{SiO}_{2}$ (45-70), $\mathrm{Al}_{2} \mathrm{O}_{3}(12-26), \mathrm{CaO}(0.7-10), \mathrm{MgO}$ (1.4-17) and $\mathrm{P}_{2} \mathrm{O}_{5}$ (0.1-1.8), and that of analyzed trace elements having the concentration (ppm) Ag (0.2-1.2), Cr (0.10-123), Ni (1.3-124), Co (11-39), Pb (25-76), Cu (126-807) and Zn (11-109).

\subsubsection{Basalt}

The volcanic rock of Ali Khanzai block have major oxides concentration (wt. \%) of $\mathrm{SiO}_{2}$ (41-53), $\mathrm{Fe}_{2} \mathrm{O}_{3}\left(0.4-1\right.$.), $\mathrm{Al}_{2} \mathrm{O}_{3}(11-26), \mathrm{TiO}_{2}(0.3-0.6), \mathrm{P}_{2} \mathrm{O}_{5}(0.1-0.5)$, $\mathrm{Na}_{2} \mathrm{O}+\mathrm{K}_{2} \mathrm{O}$ (0.4-13), $\mathrm{CaO}$ (5-11), $\mathrm{MgO}$ (4-14), and $\mathrm{MnO}$ (0.04-0.06), the analyzed trace elements of volcanic rock have the concentration (ppm) $\mathrm{Cr}(1-11)$, $\mathrm{Cu}$ (111-428), Ni (3-31), Zn (10-51), Co (5-44), Ag (0.2-1.3) and Pb (46-64).

To determine the fractionation index of gabbros, the gabbroic rocks' analysis of the Ali Khanzai block ate plotted on compositional variation diagrams of $\mathrm{MgO}$ versus $\mathrm{Al}_{2} \mathrm{O}_{3}, \mathrm{MnO}, \mathrm{CaO}, \mathrm{Na}_{2} \mathrm{O}+\mathrm{K}_{2} \mathrm{O}, \mathrm{Co}, \mathrm{Ni}, \mathrm{Cu}$ and $\mathrm{SiO}_{2}$. On the diagram (Figure 5), the $\mathrm{MgO}$ gives a positive correlation with $\mathrm{Al}_{2} \mathrm{O}_{3}, \mathrm{Fe}_{2} \mathrm{O}_{3}, \mathrm{~Pb}_{2} \mathrm{Ni}_{1}$ while with $\mathrm{CaO}, \mathrm{SiO}_{2}, \mathrm{TiO}_{2}$, and $\mathrm{Na}_{2} \mathrm{O}+\mathrm{K}_{2} \mathrm{O}$, its correlation is negative and has such no correlation with $\mathrm{Mn}$, $\mathrm{Zn}$. Co. The Ali Khanzai volcanic rocks On the fractionation index analyses (Figure 5), $\mathrm{MgO}$ show a negative relationship with $\mathrm{SiO}_{2}, \mathrm{Na}_{2} \mathrm{O}+\mathrm{K} 2 \mathrm{O}, \mathrm{CaO}, \mathrm{Cu}_{2} \mathrm{Fe}_{2} \mathrm{O}_{3}$, and having a positive relationship with $\mathrm{Zn}$, $\mathrm{Co}, \mathrm{Pb}, \mathrm{Al}_{2} \mathrm{O}_{3}$, and $\mathrm{P}_{2} \mathrm{O}_{5}$, it has no such relationship with $\mathrm{Cr}, \mathrm{Ni}, \mathrm{TiO}_{2}, \mathrm{Mn}$. 


\subsection{Discussion}

The Zhob Ophiolite is divided into three detached blocks: Naweoba, Ali Khanzai and Omzha. The Ali Khanzai block is the second-largest block after the Naweoba block. All the blocks of Zhob Ophiolites are exposed as tectonic klippe surrounded by the sediments of the Alozai Group. Lithologically, the Ali Khanzai block are mapped into ultramafic rock unit, mafic rock unit, Volcanic-volcaniclastic-pelagic sediments unit and sedimentary rock unit. Almost all the mapped units of the block are in faulted contact with one another. The alteration, deformation and mixing of these lithologies show that the Ali Khanzai block is a dismembered ophiolite body or a mélange. By comparing with major ophiolites of Pakistan; Bela [21], Muslim Bagh [4] and Waziristan [22], the nature of Zhob Ophiolite lithological units is much like that of Waziristan Ophiolite. Mineralogically, the alteration of Ali Khanzai block' rocks is shown by the presence of minerals such as chlorite, sericite, epidote, serpentinite, and pigeonite. The petrography of mantle rocks divides them into harzburgite, dunite and wehrlite, crustal plutonic rock into gabbroic, olivine gabbro, and dolerite, the volcanic rocks into basalt. The characteristics of volcanic rocks unit are similar to the Bagh Complex associated with Muslim Bagh Ophiolite and Omzha block of Zhob Ophiolite [23, 24]. Major element and a few trace element geochemical analyses divide the volcanic rocks into basaltic andesite and basaltic trachy-andesite. The compositional variation plots, of crustal plutonic and basalt rocks analyses (Figure 5) show fractionation and partial melting trends of these rocks.
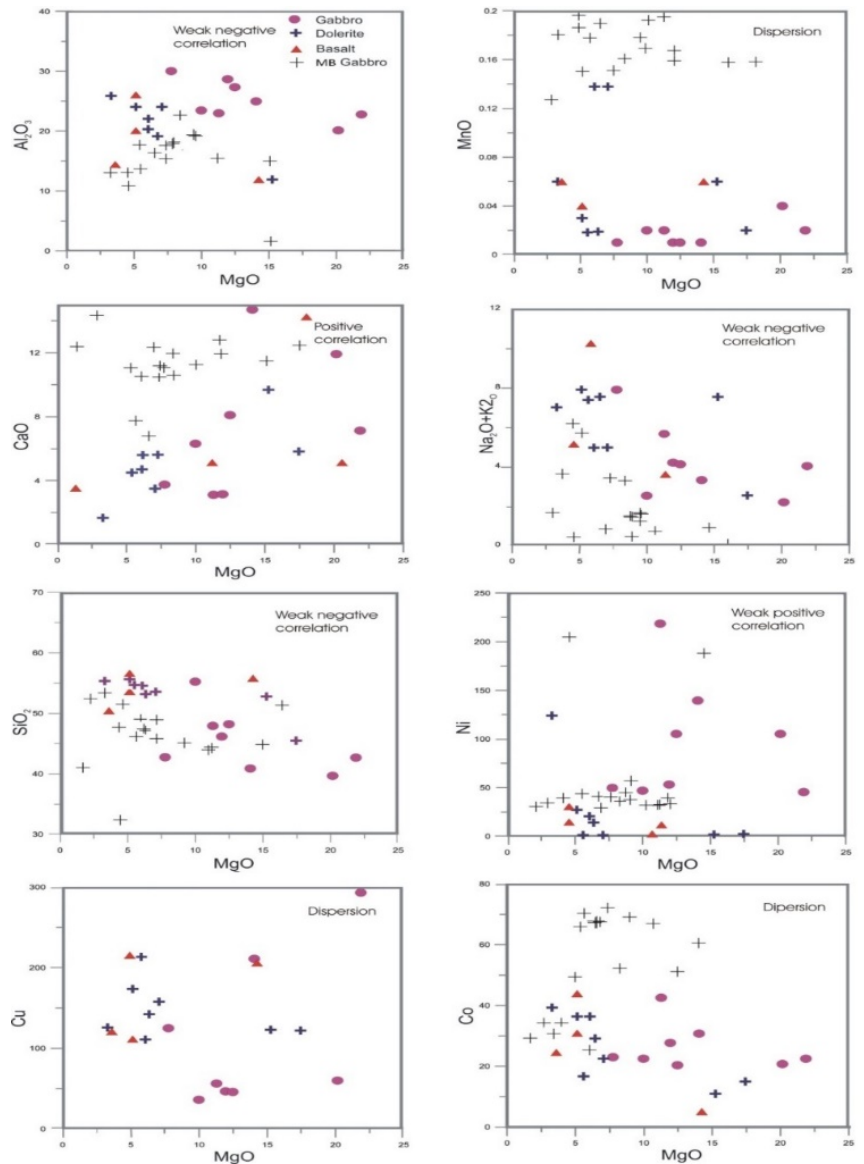

Figure 5. MgO versus selected major and trace element plots of the analyses from Ali Khanzai block of Zhob Ophiolite.

The mantle rocks are residual in nature and are much like that of Muslim Bagh Ophiolite, but are altered, deformed, and deeply weathered [25, 26]. Petrographically, mantle peridotite comprises pyroxene poor dunite with harzburgite having poor clinopyroxene ratio and these characteristics are the outcome of residual of peridotite after its melting [27]. The peridotite of the study area has altered to serpentinite and is highly distorted. The serpentinite may have formed after and during the ophiolite emplacement [28]. As many mafic dykes intruded in mantle peridotite discordantly, their nature and relationships with host rocks such as chilled margin and metamorphosed country rocks gives the way that these might be intruded late after solidification of their host rocks. The dominated harzburgite in the mantle section gives an idea that it is naturally depleted which could be the remaining product later mantle progresses such as melt-reaction and partially melting of lherzolite source [26]. The Crustal rocks unit of the Ali Khanzai block is well-exposed and are characterized by gabbro and olivine gabbro, and almost affected by alteration and deformation. The gabbroic unit has large bodies as well as small intrusions occurs within mantle peridotite, such as dykes. The gabbros are quite deformed and are having sheared, and faulted contacts with adjacent mapped units. Petrographically, the gabbros show ophitic to granular textures and the mechanical twinning in plagioclase is common, which is the significance of solid form deformation, within clinopyroxene at stable condition, with high temperature [29].

Volcanic-volcaniclastic-pelagic sediments of the block surround mantle and crustal rock units and making thrust contact with them. Much like the Bagh Complex found beneath the Muslim Bagh Ophiolite [30], the Volcanic-volcaniclastic-pelagic sediments unit might be an accretionary complex or mélange in nature, exposed here underneath the Zhob Ophiolite [30-32]. This sedimentary-igneous-assemblage named as subduction accretion compound [33] are also reported beneath the Waziristan and Bela ophiolites [34-36]. The volcanic rocks are predominantly basalts with amygdaloidal and vesicular textures, while hyaloclastite is comprised of the remains of volcanic-volcaniclastic rocks fragments, ultramafic rocks, and pelagic sediments. The pillows and tube structures in basalt are irregular and poorly developed but are closely packed and are about 0.5-1 m in diameter. Such volcanic structures indicate that these rocks are extruded in a marine environment. The metamorphic sole rocks of Ali Khanzai block may be formed during the initial intra-oceanic subduction of Zhob Ophiolite [37]. It formation is generally related to the emplacement process of an ophiolite during tectonic activity is usually accepted 
to be the result of dynamothermal metamorphism $[38,39]$. Such types of metamorphic sole rock units have also occurred beneath other ophiolites like Muslim Bagh Ophiolite [26], Khanozai Ophiolite [40] ophiolites in Turkey and Oman ophiolite [41, 42].

\subsection{Conclusion}

The following conclusions are drawn from the above conversation:

1. The Ali Khanzai block of Zhob ophiolite is the second-largest block and is mapped for the first time. It is subdivided into various sections including, ultramafic rock unit, mafic rock unit, volcanic-volcaniclastic-pelagic rocks and metamorphic sole rocks. All these units are highly deformed and having thrust contacts with one another. The ultramafic rocks identified are serpentinized harzburgite, dunite with minor wehrlite. Mafic crustal rocks are identified as normal gabbro and olivine gabbro. The volcanic-volcaniclastic are identified as basalt, tuff and hyaloclastite with associated pelagic sediments; chert, limestone, and mudstone.

2. The mantle rocks are altered, deformed, and deeply weathered, and maybe residual of enriched peridotite after its melting. The contact relationship of dolerite dykes with peridotite indicate that they might have intruded after the solidification of the host rocks. The Crustal gabbros are both large bodies as well as small intrusions that occur within mantle peridotite. They are divided into gabbro and olivine gabbro with ophitic to granular textures that may have formed from fractional crystallization in a magma chamber.

3. The volcanic-volcaniclastic-pelagic sediments surround mantle and crustal rock units. It might be an accretionary complex or mélange in nature is much like that of the Bagh Complex found beneath the Muslim Bagh Ophiolite, and other ophiolites around the world.

4. The metamorphic sole rocks are tectonically high distorted and dismembered, comprising of amphibolite and chlorite/greenschist. They might have formed through the process of early intra-oceanic emplacement.

\subsection{Acknowledgments}

This research was financially supported by the Higher Education Commission, Pakistan under its National Research Program for Universities (NRPU) Project \# 3593 to M. Ishaq Kakar.

\subsection{References}

[1] J.B. Auden, “Afghanistan-West Pakistan”,. Pp. 235-253, 1974.

[2] A.H. Robertson, "Overview of the genesis and emplacement of Mesozoic ophiolites in the Eastern Mediterranean Tethyan region", Lithos, Vol. 65, No. 1-2, Pp. 1-67, 2002.

[3] C. Dupuis, "The Yarlung Zangbo Suture Zone ophiolitic mélange (southern Tibet): new insights from geochemistry of ultramafic rocks", Journal of Asian Earth Sciences, Vol. 25, No. 6, Pp. 937-960, 2005.

[4] Kakar, "Supra-subduction zone tectonic setting of the Muslim Bagh Ophiolite, northwestern Pakistan: insights from geochemistry and petrology", Lithos, Vol. 202, Pp. 190-206, 2014.

[5] P. Tapponnier, "Mesozoic ophiolites, sutures, and arge-scale tectonic movements in Afghanistan", Earth and Planetary Science Letters, Vol. 52, No. 2, Pp. 355-371, 1981.

[6] E. Gnos, A. Immenhauser, and T. Peters, "Late Cretaceous/early Tertiary convergence between the Indian and Arabian plates recorded in ophiolites and related sediments." Tectonophysics, Vol. 271, No. 1-2, Pp. 1-19, 1997.

[7] A. Popal, M.I. Kakar, and M. Khan, "Geology and petrography of gabbroic rocks from Khanozai Ophiolite, Northwestern Pakistan", International Research Journal of Earth Sciences, Vol. 7, No. 3, Pp. 3, 2019.

[8] Kazmi and M.Q. Jan, "Geology and tectonics of Pakistan", Graphic publishers, 1997.

[9] A. Sengor, "Tectonics of the Tethysides: orogenic collage development in a collisional setting", Annual Review of Earth and Planetary Sciences, Vol. 15, No. 1, Pp. 213-244, 1987.

[10] A. Gansser, "Reconnaissance visit to the ophiolites in Baluchistan and the Himalaya", Geodynamics of Pakistan, Pp. 193-213, 1979.

[11] A. Jones, "Reconnaissance Geology of part of West Pakistan (Colombo Plan co-operative project conducted and compiled by Hunting Survey Corporation)", Government of Canada, Toronto, 1960.

[12] T. Naka, "Mesozoic sedimentary-igneous Complex, Bagh complex, in the Muslim Bagh Area, Pakistan. opening and closing ages of the Ceno-Tetheyan branch. in Proceedings of Geoscience Colloquium, Geoscience Laboratory", Geological Survey of Pakistan. 1996.

[13] A.K. Kasi, "Revised lithostratigraphy of the Pishin Belt, northwestern Pakistan", Journal of Himalayan Earth Science, Vol. 45, No. 1, 2012.

[14] F. Allemann, "Time of emplacement of the Zhob Valley ophiolites and Bela ophiolites, Baluchistan (preliminary report)", Geodynamics of Pakistan. Geological Survey of Pakistan, Quetta, Pp. 215-242, 1979.

[15] M. Qayyum, A.R. Niem, and R.D. Lawrence, "Newly discovered Paleogene deltaic sequence in Katawaz basin, Pakistan, and its tectonic implications", Geology, Vol. 24, No. 9, Pp. 835-838, 1996.

[16] E. Macalalad, "A concise analytical scheme for 16 trace elements in geochemical exploration samples using exclusively AAS", Journal of Geochemical Exploration, Vol. 30, No. 1-3, Pp. 167-177, 1988.

[17] M.D. Williams, "Stratigraphy of the Lower Indus Basin, West Pakistan", in 5th World petroleum congress, World Petroleum Congress, 1959. 
[18] A. Fatmi, I. Hyderi, and M. Anwar, "Occurrence of the Lower Jurassic Ammonoid genus Bouleiceras from the surghar range with a revised nomenclature of the Mesozoic Rocks of the Salt Range and Trans Indus Ranges (Upper Indus Basin)”, Geol. Bull. Punjab Univ, Vol. 25, Pp. 38-46, 1990.

[19] K. Cox, J. Bell, and R. Pankhurst, “The Interpretation of Igneous Rocks”, Allen and Unwine, London, Pp. 450, 1979.

[20] M.L. Bas, "A chemical classification of volcanic rocks based on the total alkali-silica diagram", Vol. 27, No. 3, Pp. 745-750, 1986.

[21] G. Sarwar, "Tectonic setting of the Bela Ophiolites, southern Pakistan”, Tectonophysics, Vol. 207, No. 3-4, Pp. 359-381, 1992.

[22] Khan, "Petrology of the dykes from the Waziristan Ophiolite, NW Pakistan", Journal of Asian Earth Sciences, Vol. 29, No. 2-3, Pp. 369-377, 2007.

[23] A. Ahmed, "Geology and Petrology of Omzha Block, Zhob Ophiolite, northern Balochistan, Pakistan. 2020.

[24] M.I. Kakar, "Geochemistry and petrogenesis of the volcanic rocks from Bagh complex, northern Balochistan, Pakistan, Vol. 45, No. 1, 2012.

[25] M.I. Kakar, "Petrology, Geochemistry and tectonic setting of the Muslim Bagh ophiolite, Balochistan, Pakistan. Unpublished Ph. D. Thesis, Centre of Excellence in Mineralogy", University of Balochistan, Quetta, Pp. 265, 2011.

[26] M.I. Kakar, "Petrology of the mantle rocks from the Muslim Bagh Ophiolite, Balochistan, Pakistan”, Journal of Himalayan Earth Science, Vol. 46, No. 2, 2013.

[27] A. Nicolas, "Structures of ophiolites and dynamics of oceanic lithosphere”, Springer Science \& Business Media, Vol. 4, 2012.

[28] M. Mahmood, and M. Khan, "Structural characteristics of gabbroic rocks from Saplai Tor ghar massif, Muslim Bagh ophiolite, Pakistan", Acta Minalogica Pakistanica, Vol. 10, Pp. 37-44, 1999.

[29] Kakar, "U-Pb zircon crystallization age of the Muslim Bagh ophiolite: Enigmatic remains of an extensive pre-Himalayan arc", Geology, Vol. 40, No. 12, Pp. 1099-1102, 2012.

[30] J. Mengal, "The lithology and structure of a Mesozoic Sedimentary-igneous assemblage beneath the Muslim Bagh ophiolite, Northern Balochistan, Pakistan", Bulletin of the Geological Survey of Japan, Vol. 45, Pp. 51-61, 1994.

[31] Y. Sawada, "Mesozoic igneous activity in the Muslim Bagh area, Pakistan, with special reference to hotspot magmatism related to the break-up of the Gondwanaland. in Proceedings of Geoscience Colloquium Geoscience Laboratory, Geological Survey of Pakistan. 1992.

[32] Y. Dilek, and M.F. Flower, "Arc-trench rollback and forearc accretion: 2. A model template for ophiolites in Albania, Cyprus, and Oman", Geological Society, London, Special Publications, Vol. 218, No. 1, Pp. 43-68, 2003.

[33] R.A. Beck, "Stratigraphic evidence for an early collision between northwest India and Asia”, Nature Australia, Vol. 373, Pp. 55-58, 1995.

[34] E. Gnos, "Bela oceanic lithosphere assemblage and its relation to the Reunion hotspot", Terra Nova-Oxford-, Vol. 10, Pp. 90-95, 1998.

[35] M. Khan, "Petrological and Structural studies of the Ophiolite of the Baran Lak Area", Bela-Khuzdar, District, Balochistan, Pakistan, Pp. 147, 1999.

[36] A. Nicolas, "Structures of ophiolites and dynamics of oceaniclithosphere", Kluwer Academic Publishing, Dordrecht, Vol. 4, Pp. 367, 1989.

[37] R.A. Jamieson, "P-T paths from high temperature shear zones beneath ophiolites", Journal of Metamorphic Geology, Vol. 4, No. 1, Pp. 3-22, 1986.

[38] J. Malpas, "The dynamothermal aureole of the Bay of Islands ophiolite suite”, Canadian Journal of Earth Sciences, Vol. 16, No. 11, Pp. 2086-2101, 1979.

[39] Haq, "Petrology And Major Element Geochemistry Of Mantle Rocks From Khanozai Ophiolite, Northern Balochistan, Pakistan", Bahria University Research Journal of Earth Sciences, Vol. 4, No. 1, Pp. 26-32, 2019.

[40] J.N. Lytwyn, and J.F. Casey, "The geochemistry of postkinematic mafic dike swarms and subophiolitic metabasites, Pozanti-Karsanti ophiolite, Turkey: Evidence for ridge subduction", Geological Society of America Bulletin, Vol. 107, No. 7, Pp. 830-850, 1995.

[41] O.F. Çelik, and M.F. Delaloye, "Characteristics of ophiolite-related metamorphic rocks in the Beysehir ophiolitic mélange (Central Taurides, Turkey), deduced from whole rock and mineral chemistry", Journal of Asian Earth Sciences, Vol. 26, No. 5, Pp. 461-476, 2006.

[42] D.L. Whitney, and B.W.J.A.M. Evans, “Abbreviations for names of rock-forming minerals”, Vol. 95, No. 1, Pp. 185-187, 2010. 